\title{
Veracity in Alana Valentine's Ladies Day: Implications for Research-Informed Theater
}

\author{
Tara Goldstein
}

\author{
Version Pre-print/submitted manuscript \\ Citation Goldstein, T. (2017). Veracity in Alana Valentine's Ladies Day: \\ (published version) Implications for research-informed theatre. Qualitative Inquiry, \\ 23(6):438-444. doi: 10.1177/1077800416673661.
}

Publisher's Statement This is the submitted manuscript of an article published in the journal Qualitative Inquiry. This article has been reprinted by permission of SAGE Publications.

Copyright (C) 2017 (Tara Goldstein)

How to cite TSpace items

Always cite the published version, so the author(s) will receive recognition through services that track citation counts, e.g. Scopus. If you need to cite the page number of the author manuscript from TSpace because you cannot access the published version, then cite the TSpace version in addition to the published version using the permanent URI (handle) found on the record page.

This article was made openly accessible by $U$ of $T$ Faculty. Please tell us how this access benefits you. Your story matters. 


\section{Veracity in Alana Valentine's Ladies Day: Implications for Research-Informed Theatre}

Tara Goldstein, $\mathrm{PhD}$

Department of Curriculum, Teaching and Learning

Ontario Institute for Studies in Education, University of Toronto

252 Bloor Street West

Toronto, Ontario

Canada

M5S 1V6

416-975-4000

\section{Biographical Statement}

Tara Goldstein is a professor, critical ethnographer and playwright in the Department of Curriculum, Teaching and Learning at the Ontario Institute of Studies in Education, University of Toronto, where she is pursuing a teaching and research program in performed ethnography for critical teacher education. Tara has completed eleven research-informed theatre scripts, which have been read aloud, performed and discussed across Canada, the United States, Australia and in Bogotá, Colombia. 


\title{
Veracity in Alana Valentine's Ladies Day: Implications for Research-Informed Theatre
}

\begin{abstract}
This article introduces the reader to the work of Australian verbatim playwright Alana Valentine and examines the ways she raises the issue of veracity or truthfulness in her 2016 verbatim play Ladies Day. The article begins with a brief description of verbatim theatre and the importance of veracity in verbatim theatre and research-informed theatre. It then moves to an analysis of the way Valentine takes up issues of veracity in Ladies Day. The article concludes with a discussion of the implications Valentine's work has for research-informed theatre practitioners in the social sciences.
\end{abstract}

\section{Introduction}

In this article I want to introduce the readers of Qualitative Inquiry to the work of Australian verbatim playwright Alana Valentine and examine how she raises the issue of veracity or truthfulness in her 2016 play Ladies Day. I also want to discuss the implications Valentine's meditation on veracity has for social science researchers who use dramatic scripts and performances to share their findings. I will use the umbrella term "research-informed theatre" to describe the work of these researchers knowing that there are important differences between plays that have been called performed ethnography, performance ethnography, ethnodrama, verbatim theatre and documentary theatre $^{1}$.

I begin the article with a brief description of verbatim theatre and a brief discussion of the importance of veracity in verbatim theatre and research-informed theatre. I then move to an analysis of the way Valentine takes up issues of veracity or 
truthfulness in Ladies Day. Finally, I reflect on the implications Valentine's work has for research-informed theatre practitioners.

\section{Verbatim theatre}

Verbatim theatre has been described by its practitioners as "stories from real life; "a piece of theatre [made] by interviewing people"; "work that draws in some way from real life or a community"; "a commitment to put ... the voice of that community on stage with some felicity to the way they speak," and "work which ... has some ethical obligation back to that community" (Brown and Wake 2010, p.2). The term "verbatim" refers to the origins of the words spoken in a verbatim play. The words of real people are recorded or transcribed by a playwright during an interview or are appropriated from existing records such as the transcripts of a court hearing. The words are then edited, arranged and/or recontextualized to form a dramatic script that can be performed on stage by actors who take on the characters of the real individuals whose words are being used (Hammond and Steward 2008, p.9).

Verbatim theatre, which has roots as far back as the drama of late eighteenthcentury Germany (Garde, Mumford, and Wake 2010) ${ }^{2}$, has become very popular in North America, the United Kingdom and Australia in the last two decades. In Britain, some verbatim theatre practitioners believe their projects are beginning to displace mainstream media as a way for the public to access reliable information about current political events (Brown and Wake 2010). These practitioners argue mainstream media can no longer be trusted to tell the truth about events such as the Gulf Wars and the so-called War on Terror. For example, Richard Norton-Taylor's (2007) play Called to Account: The Indictment of Anthony Charles Lynton Blair for the Crime of Aggression Against Iraq: A 
Hearing is one of several British verbatim plays that was produced in the aftermath of Britain's involvement in the invasion of Iraq to provide audiences with facts about the invasion they did not hear in the media (Brown and Wake 2010).

The goal of verbatim theatre to provide reliable information to audiences raises a key question for its practitioners: What counts as veracity or truthfulness in verbatim theatre? As Hammond and Steward (2008) state, the claim to veracity on the part of the theatre makers changes everything. When audience members approach a verbatim play as an accurate source of information they expect the playwright is telling the truth and they are not being lied to. Likewise, audiences of research-informed theatre expect the story they are seeing on stage is truthful and accurate. Researchers sharing their findings through staged performances must follow an ethical code and high standards practice if their work is to be taken seriously. While all verbatim and research-informed theatre practitioners (like qualitative researchers) interpret their research findings to create a story and/or an argument, they must be prepared to discuss the ways they have worked to ensure the stories their plays tell are accurate and truthful. In Ladies Day, verbatim playwright Alana Valentine has included such a discussion as part of her play.

\section{Alana Valentine}

Alana Valentine has been writing verbatim plays for last twelve years using both "pure verbatim" and "massaged verbatim" techniques. She has described her first verbatim play Run Rabbit Run (2004) as a pure verbatim play. The play is based on interviews with people in South Sydney who were campaigning for their rugby team The Rabbitohs to regain the right to play in the country's National Rugby League. Valentine carefully transcribed each of the interviews and presented them as stories told by real 
people. She calls her second verbatim play Parramata Girls (2007) a "massaged verbatim" play because she shaped the interview talk she collected into a story. The play draws on interviews with women who were abused as girls at the Girls Training School (GTS) in Paramatta, New South Wales. The story is simple: A group of women who attended GTS come back to the institution for reunion, look around, talk to each other and leave. Yet, as simple as it is, the story allows Valentine to trace the women's personal struggles as they look back on the abuse they endured at GTS, share their memories of abuse with other women at the reunion, and talk about moving forward with their lives (Oades 2010, p.60).

\section{Ladies Day}

Ladies Day premiered at The Griffith Theatre in Sydney in February 2016 during Mardi-Gras, Sydney's month long celebration of LGBTQI (Lesbian, Gay, Bisexual, Transgender, Queer, Intersex) Pride. It is a verbatim play about living as a gay man in regional Australia. The term regional is used in Australia to refer to towns and communities that are located outside of the country's cosmopolitan cities. The play is based on interviews Valentine undertook with gay men living in the resort town of Broome, other communities on the Kimberly Coast, and in the Northern Territory town of Darwin and community of Katherine. In an interview with The Sydney Morning Herald, Valentine describes Ladies Day as another one of her "massaged" verbatim plays:

I like to think of my work on a spectrum that ranges from pure verbatim to fiction. Ladies Day sits at the halfway mark, maybe leaning more towards the fictional end. The characters are amalgamations and conflations of real people and so are some of the events, but it's a very massaged version of real events (Blake 2016). 
In her Playwright's Note about the play, Valentine comments on her amalgamations and conflations of real people:

Given my own sustained relationship with the GLBTI of Sydney (and elsewhere) it would be fair to say that much of my life has contributed to the portraits of the characters in this drama. The line between truth and fiction is one which audiences themselves must draw. My sincere contract with the audience for Ladies Day is that I hope this work is no less true for being an artifice of conflations, amalgamations, and combinations of stories drawn from real life (Valentine 2016, p.60).

To help the audience draw its own conclusions about the veracity or truthfulness about her story Valentine includes a character to represent herself, a verbatim playwright interviewing gay men living in Broome. The character is called Lorena and she appears for the first time in scene two of the play, where she talks about the two hardest things she's ever done: masturbate when someone has asked her and writing herself into one of her plays.

\section{LORENA}

So the second hardest thing I have ever done is this, include myself in my own play. Because I am better at telling other people's stories. At least I'm more comfortable. I know that for every artist it's always about yourself even when it is about someone else, but just for a moment, ignoring the universal theme line and facing the fact that I am putting myself in my own play, this story of a writer who goes to Broome and what happens to her is the second hardest thing I have ever done. Because it is just like the hardest thing I mentioned, just so personal.

Where we really live, what whispers to us, what haunts us, what helps us, what drives us. People can't always talk about that straight out. Can't always put it into words.

And then, just sometimes, you meet someone who can. But not the way you expect (Valentine, 2016, p.3).

By naming the project of including herself in one of her plays as the second hardest

thing she's ever done, and juxtaposing it against the first hardest thing she's ever done 
Valentine reveals just how vulnerable she feels in sharing her reflections on the veracity of her work with her audiences. But difficult as it is, she forges ahead.

Spoiler Alert: The rest of the article discusses a part of the play that is meant to be a surprise. If you don't want the surprise to be ruined, read the play first, and then continue reading the article.

The last two lines in scene two talk about how a playwright sometimes meets someone who talks about where they live in a way that is unexpected. These lines foreshadow the surprising end of the play when Lorena finds out that Mike, one of the men she has interviewed, has lied to her.

Mike is a newcomer to Broome and the audience follows him as he meets other gay men in town. In scene seven Mike meets John at Ladies Day at the Broome races. On Ladies Day, some of the gay men attend the races in dresses. Mike is wearing lingerie, a frock, hat, make-up and women's shoes. In the stage directions Valentine writes

He looks divinely beautiful. Sexy and gorgeous. This is not eighties drag with bad foundation and a nasty wig - this is glorious, genuinely elegant glamour on a man (Valentine 2016, p.6).

When Mike first meets John, John is hammering a horseshoe on an anvil. Mike describes him as a Queer Cowboy. John begins flirting with Mike and the two move quickly into a sexual encounter until Mike insists John use a condom. Suddenly John hits Mike with the horseshoe. He is insulted Mike thinks he's "diseased". John continues to hit Mike, brutally rapes him, and then hits him again, this time in the head, knocking him unconscious. John continues kicking Mike in the stomach and back. Again and again, until he kneels down and begins to cry. When he recovers John drags Mike offstage, leaving a trail of blood. 
Mike survives the rape and the beating and tells Lorena about the violent attack.

The audience isn't privy to Mike's interview with Lorena. We hear about it in an interview Lorena has with another character, Rodney, in scene thirteen.

I heard a story.

\section{LORENA}

RODNEY

From whom?

LORENA

I heard a story about how Broome is not so tolerant.

RODNEY

And one story makes the town intolerant, does it?

LORENA

Can we just cool this down a little?

RODNEY

Don't portray Broome as bigoted. Because it's not.

LORENA

There are bigots everywhere. There are incidents everywhere. Including Broome.

Why are you digging?

RODNEY

LORENA

Who says I am?

RODNEY

Well, no one has ever said anything to me.

LORENA

Well, you're not me.

What does that mean?

RODNEY

I mean, I'm good at this.

\section{LORENA}


Good at what?

\section{RODNEY}

LORENA

I'm a good listener.

RODNEY

So people tell you things they don't say to anyone else?

\section{LORENA}

Which is important, isn't it?

\section{RODNEY}

You're like a snake charmer. You charm stories out of people and before they know it they're telling you stuff they've never told anyone and it does them no good to dwell on.

\section{LORENA}

Says you.

\section{RODNEY}

Everyone says it's tolerant and suddenly you're suspicious.

\section{LORENA}

I think it depends on who you ask.

\section{RODNEY}

People are going to want to impress you (Valentine 2016, p.27-28).

Invested in the representation of Broome as a tolerant community, Rodney questions Lorena about the stories of bigotry and intolerance she says she has heard. He says he hasn't heard of any homophobic incidents. He thinks the people Lorena is talking to are telling her about homophobic incidents because they're trying to impress her. Rodney implies the people who have talked to Lorena about intolerance may be exaggerating the truth or not telling the truth. In giving voice to Rodney's critique, Valentine raises a question many verbatim playwrights and research-informed theatre practitioners ask themselves: How true are the stories I am hearing in my interviews? 
At this point of the play, having witnessed Mike's brutal rape and beating on stage, the audience is prepared to believe there has been at least one violent homophobic incident in Broome, and Lorena is justified in including the incident in her play. We are prepared to believe her when she says, "There are incidents everywhere. Including Broome." Importantly, the audience also belives that Rodney knows about the rape because he was the doctor who was called to help Mike after Liam, a good friend of Mike's, found him lying on the floor badly injured and semi-conscious.

Our belief that a rape took place at Ladies Day deepens as we follow the story of what happens after Mike reports the rape to a Broome police officer named Therese. We see Mike drawing the face of his attacker in crayons on the wall of Liam's living room, we hear Liam suggest Mike see a counselor, we hear Mike talk about his session with the counselor in a monologue, we see Mike and Liam find John and confront him about the rape, we see Mike and Liam try to give John "a taste of what [it] is like" to be raped, we see Therese interrupt the payback rape, we see John pull a knife, we see Mike run into John's knife, we hear Therese shout, "Call the ambulance”, we see Therese charge John with grievous bodily harm and sexual assault, we see Mike slice John's throat and we see John die. But then Valentine complicates our understanding of what actually happened and what is actually true in scene twenty-three when Liam tells her he and Mike have lied about murdering John.

\section{LIAM}

You're not really going to put it in your play, are you? The whole story, like the murder and that?

\section{LORENA}

Well... yeah. I am (the ellipsis here appears in the play script). 


\section{LIAM}

Nah, I don't think that's a good idea.

LORENA

Right.

LIAM

It's not something you want out there... you know. Made public (the ellipsis here appears in the play script).

\section{LORENA}

Okay. But I've got to ask. Why did you tell me if you didn't want it out there.

Yeah.

\section{LIAM}

LORENA

I mean, you have signed a release and everything, saying I can include it.

LIAM

Right. Yeah. But the thing is... (the ellipsis here appears in the play script)

Pause.

We may have exaggerated a bit.

LORENA

What do you mean exaggerated? ... (the ellipsis here is mine).

LIAM

... I mean lied (the ellipsis here is mine).

Lied.

LORENA

A bit.

LIAM

Which bit?

LORENA

Which bit?

LIAM

All of it. 


\section{LORENA}

All of what happened to Mike?

LIAM

Sort of.

Pause. LORENA involuntarily moves backward from him, like a crab.

LORENA

No.

\section{LIAM}

Sorry...we told you the version of John that Mike has sort of dressed up (the ellipsis here is mine).

Pause.

\section{LORENA}

No you didn't...Please tell me you didn't lie (the ellipsis here is mine).

MIKE enters.

MIKE

You told her?

Yep.

LIAM

MIKE

I can tell. From her face. She's not pleased.

LORENA

I don't believe you...you were never raped? (the ellipsis here is mine)

Pause.

MIKE

I was raped just like that, by a person, my partner, who I'd been with for nearly a year. All I've changed is the setting. He'd been controlling and then he became violent and I was so ashamed I couldn't tell anyone. And then he raped me.

Pause.

And I left him and then I came to Broome.

Why didn't you tell me that?

\section{LORENA}


It's not much of a story.

\section{LORENA}

It's a horrific story.

\section{MIKE}

Not really. Not like bashed in a dress at the Broome races and then a knife to the throat in a motel clinch.

\section{LORENA (angry)}

And that's why you lied? Because it's a better story? ... No one has lied to me before (the ellipsis here is mine).

Yeah, they have.

LIAM

Yeah, they have.

MIKE

Why do you tell other people's stories?

What?

\section{LORENA}

MIKE

Why have you always told other people's stories and not your own?

\section{LORENA}

I've told my own story through other people.

\section{MIKE}

And that's what I've done too (Valentine 2016, pp.53-55).

As Mike's admission of having lied begins to sink in, Lorena's angry turns to fury.

Mike defends himself.

MIKE

John may not be real, but he's true.

In your mind.

\section{LORENA}

Don't say it like it's nothing.

\section{LIAM}


What?

\section{LORENA}

\section{MIKE}

Listen. I tell you what actually happened to me and I flip it off because that's what I need to do. Pfff. It was nothing. But just because I tell myself it's nothing and I tell other people it's nothing... doesn't mean there's nothing in here (the ellipsis here appears in the play script).

\section{LORENA}

Yeah, well, I don't deal with in there. I deal with what really happened.

\section{LIAM}

Why? You're not a journalist, are you?

\section{LORENA}

No, I'm not, but I'm after veracity, I'm after authenticity.

\section{MIKE}

Listen sweetness, you want to know why? Because this is my life in here. In here, John stalks me and controls me and assaults me, over and over and over. And the only way I can make it real, the only way I can dodge my own... stuff... about how this should have been the love of my life... how he was the one and then he was this ... monster, is to make him into this...I thought you might understand (the ellipses used in these lines appear in the play script) (Valentine 2016, p.56).

The story of the lie begins when Liam asks Lorena not to put the story about the murder into her play. Lorena is surprised. Liam and Mike told her the story for a reason and they signed a release form agreeing to have their story appear in the script. Lorena's reference to the release form establishes she has followed the standard practice of ensuring she has permission to use the words of the people she has interviewed in her play. When Lorena understands Liam doesn't want the story of the murder included because he and Mike lied about it, she is stunned and "backs away like a crab" (p.54). Lorena tells Liam no one has ever lied to her before. Liam believes this is naïve: "Yeah, they have," he says (p.55). 
When Mike enters the scene he explains he was, indeed, raped. But not by John, and not in Broome. He was raped by his partner. For Mike, the story he told Lorena about the rape is actually true. "All I've changed is the setting" (p.55). But Lorena is looking for veracity and authenticity ${ }^{3}$. Changing the setting makes the story less accurate, less truthful. She asks Mike why he just didn't tell her the story of being raped by his partner. Mike says that story wasn't as good as the story he told her. Lorena is incredulous. For a verbatim theatre practitioner the only story worth telling is the story that really happened. But Mike continues to argue for the truthfulness of his story: Just like Lorena who tells her own story through the stories of other people, the only way he could tell the story of being raped by his partner was to attribute the rape to another person.

Mike's argument here is compelling. Two scenes earlier Lorena shared a personal story of being sexually assaulted by five teenage boys when she was a teenager. The first boy who assaulted her was a boy she had a crush on. It is a horrific story. The way Mike's story is a horrific story. And because Lorena has shared the story of her own sexual assault with the audience we understand why she may be so interested in including Mike's rape story in her play. Sharing Mike's story is another way of sharing her own story.

Like Lorena the audience has been lied to. Valentine had us witness John's rape of Mike on stage so we would truly believe it had taken place at the races in Broome on Ladies Day. So like Lorena we are stunned to learn Liam and Mike lied. We are now deeply involved in the question of what is true and what is not true about Liam and Mike's story of the rape. We are also involved in the more complicated question of how 
Liam and Mike's story is true. We understand Mike's need to tell the story of being raped by his partner through the imaginary character of the John, the Queer Cowboy. We understand for Mike "John may not be real, but he is true" (p.56). But we also know representing a rape that happened outside of Broome as a rape that happened in Broome is not accurate. Furthermore, we know that such a representation has consequences for Broome, which is a resort town working hard to be seen as tolerant so it can attract gay tourists.

The story of the lie continues with Mike and Liam telling Lorena that as a playwright she too has lied. Lorena denies this.

\section{LORENA}

No.

Yes.

MIKE

\section{LORENA}

No.

MIKE

Yes.

LIAM

You've shaped the story, though.

Pause.

Yes.

\section{LORENA}

MIKE

Which is fine.

LIAM

Because your job is fascination.

MIKE

You are a fascinator. 
Here Valentine is provoking the audience to not only ask themselves what is true and what is not true in her story of gay life in Broome, but to consider the claims of verbatim theatre that it is more reliable than other media. If a verbatim theatre practitioner shapes her story of an event is she any different than journalists who shape their story of an event? Verbatim theatre practitioner David Hare answers this question by arguing people who work in the theatre have much less to gain from lies and spin, and much more interest in being honest (Hammond and Steward, p.10). But Valentine provokes the audience to wonder to what extent this is true. If the playwright's job is to fascinate her audience, will she exaggerate or lie to tell a story that is compelling?

The story of the lie comes to an end when Mike asks Lorena if she will make the story of John real. This the audience now understands would involve lying to the audience about the rape having taken place in Broome.

So can John be real?

\section{LORENA}

No?

He is.

Is he?

\section{LORENA}

LIAM

You can make him real.

MIKE

Yes. No.

\section{LORENA}

\section{Long pause.}




\section{Maybe.}

\section{LORENA}

Lorena's response of "maybe" allows her to begin thinking of a way to honour Mike's belief that his story of John is real but not let the audience leave the theatre thinking that Mike's rape took place in Broome. The result of that thinking is Ladies Day, a play that lies to the audience to tell them a complex set of truths about violence against gay men.

The play ends with Lorena listening Rodney's interview on her recording device. Rodney's words tie Valentine's meditation on truth telling in verbatim theatre to truth telling in gay communities in regional Australia.

\section{RODNEY}

I do know some guys who have never come to grips with the sexuality ... People can't who say things about themselves, so they tell stories. Maybe they're not lying, they're telling the truth their way ... There's a lot of people in the Kimberley and in the Territory with a lot secrets...

...Before I came to Broome I was living a version of something. Now I'm going to be me. Any version of me that suits me. Okay? (the ellipses that appear here are mine).

Rodney's words ends the play and the audience is left with the understanding that some gay men in the Kimberley and the Territory are in the closet and need to tell stories about their lives. Others, like Rodney, feel they can be themselves. Mike's lie about the rape, then, does represent an authentic experience for some gay men in the communities Valentine visited. Valentine has been able to achieve both veracity and authenticity in Ladies Day by lying.

\section{Implications for Research-Informed Theatre Practitioners}

Alana Valentine's choice to lie to her audience is a bold choice. Especially right now in a moment when verbatim theatre is perceived by some to be superior to 
mainstream journalism for delivering reliable information. Mike's insight that Lorena's job as a playwright is to fascinate her audience reminds research-informed theatre practitioners that there is a real tension between their job to tell compelling stories and their job to provide reliable information. I have written about this tension before and have argued that research-informed theatre practitioners must find a way to negotiate conflicting commitments to veracity, authenticity, and theatricality (Goldstein 2008; Goldstein et al 2014). Alana Valentine has chosen to put the conflict between these different commitments on stage and ask her audience to engage in the conflict with her. My work in this article can be seen as an example of such engagement.

I have argued the reason Valentine has been successful in staging a lie to tell a complex set of truths is because she was willing to put herself into her play as a character. This required making herself vulnerable and putting her own personal story of violence on stage. This too is a bold choice.

In her now classic article on creative analytic practice, sociologist Laurel Richardson (2000) argues researcher-artists must show how they came to write their story. Playwrights must show how they gathered the information embedded in their play, how they have held themselves accountable to high standards of understanding and writing about the people they have studied, and how their point of view may have impacted on their telling of their story. Most research-informed theatre practitioners do this kind of reflexive work outside the story of their play, in Playwright's Notes at the beginning or end of their published scripts or in the program that accompanies their performances. Alana Valentine has provided us with an example of how such reflexivity can be shared within a play itself. Doing so required creativity, boldness and courage. 
The same kind of creativity, boldness and courage it takes to live as a gay man in

Broome. And everywhere else.

In memory of the forty-nine people who died inside Pulse, a gay nightclub in

Orlando, Florida, during a mass shooting that has been described as the most deadly

mass shooting in the United States of America.

\section{References}

Blake, Elissa (2016). Alana Valentine's race-day tribute lines up at the gay barrier. Sydney Morning Herald, Feb 12, 2016, http://www.smh.com.au/entertainment/alana-valentines-raceday-tribute-lines-up-atthe-gay-barrier-20160211-gmr8uj.html

Brown, Paul and Wake, Caroline. (2010). Towards a working definition of verbatim theatre. In P. Brown (Ed.). Verbatim: Staging Memory and Community. Strawberry Hills, NWS: Currency Press, pp. 2-5.

Denzin, Norman. (2003). Performance Ethnography: Critical Pedagogy and the Politics of Culture. Thousand Oaks, CA: Sage.

Goldstein, Tara, Gray, Julia, Salisbury, Jenny and Snell, Pam. (2014). When qualitative research meets theatre: Performed ethnography and research-informed theatre project design. Qualitative Inquiry, 20(5) 674-685.

Goldstein, Tara. (2012) Staging Harriet's House: Writing and Producing ResearchInformed Theatre. New York, NY: Peter Lang. Includes the play Harriet's House.

Goldstein, Tara. (2008) Performed Ethnography: Possibilities, Multiple Commitments, and the Pursuit of Rigour. In Gallagher, K. (Ed.). The Methodological Dilemma: Critical, Creative, and Post-Positivist Approaches to Qualitative Research. New York, NY: Routledge, pp.85102.

Garde, Ulrike, Mumford, Meg, and Wake, Caroline (2010). A short history of verbatim theatre. In P. Brown (Ed.). Verbatim: Staging Memory and Community. Strawberry Hills, NWS: Currency Press, pp. 9-17.

Hammond, W. and Stewart, D. (2008). Verbatim Verbatim: Contemporary Documentary Theatre. London: Oberon Books.

Norton-Taylor, R. (Ed.), and Kent, N. (Deviser). (2007) Called to Account. London: Oberon Books. 
Oades, Rosyln. (2010). Parramatta Girls: Verbatim theatre about the forgotten Australians. In P. Brown (Ed.). Verbatim: Staging Memory and Community. Strawberry Hills, NWS: Currency Press, pp. 59-66.

Richardson, L. (2000). Writing: A method of inquiry. In: Denzin, Norman, and Lincoln, Yvonne. (Eds.). Handbook of Qualitative Research. $2^{\text {nd }}$ Edition. Thousand Oaks, CA: Sage, pp.923-948.

Valentine, Alana. (2016). Ladies Day. Sydney: Currency Press.

\footnotetext{
${ }^{1}$ For a review of these differences see Goldstein 2012 chapter 1.

2 In their short history of verbatim theatre Garde, Mumford and Wake trace the development of verbatim theatre from the drama of eighteenth-century Germany to the first documentary dramas by German medical scientist George Büchner (1813-1837) to the Living Newspaper shows staged in the Union of the Soviet Socialist Republics (the USSR) to present information about the progress of the Russian revolution to the political theatre of Erwin Piscator (1893-1966) in Germany in the 1920s to the American Federal Theatre Project's American Living Newspaper shows produced during the Depression years to the "second wave" of documentary theatre in the 1960s and 70s in West Germany and Britain to the emergence of verbatim theatre as a distinct form in Britain in the 1960s and 70s. They also discuss American Emily Mann's verbatim theatre work in late 1970s and early 80s, American Anna Deavere Smith's work in the early 1990s and a range of Australian verbatim theatre projects that were produced in the 1990 s and 2000s.

${ }^{3}$ See Richardson 2000, Denzin 2003 and Goldstein 2012 chapter 3 for a discussion of authenticity in research-informed theatre.
} 